\title{
PRACTITIONER RESEARCH IN THE PRACTICE AND EDUCATION OF HEALTHCARE PROFESSIONALS IN THE NETHERLANDS
}

\author{
Cyrilla van der Donk $k^{1}$ Bas van Lanen ${ }^{2}$
}

\footnotetext{
${ }^{1}$ Master of Arts. Lecturer and researcher, HAN University of Applied Sciences. Nijmegen, Netherlands. E-mail: cyrilla.vanderdonk@ han.nl

${ }^{2}$ Master of Science. School vice principal and researcher, Stichting StisamO. Elst, Netherlands. E-mail: basvanlanen@gmail.com
}

\begin{abstract}
Objective: the purpose of this study is to explore the increased attention for practitioner research in the practice of healthcare professionals in the Netherlands and its consequences for the implementation of research in higher professional healthcare education.

Method: this study is a reflection based on a literature review.

Results: recent developments in the practice of healthcare professionals in the Netherlands have led to the belief that an analytic, inquisitive and reflective capacity is playing an increasingly important role for healthcare professionals to function optimally and to improve clinical practice through innovation. In the Netherlands professionals in healthcare carry out practitioner research projects to construct local knowledge and improve their own professional practice. Increasingly, institutes for higher professional healthcare education have implemented continuous research curricular strands to teach students to conduct practitioner research.

Conclusion: practitioner research is seen as an effective professional learning strategy that promotes the use of theory and recognizes practical knowledge and expertise of the healthcare professionals and their patients and clients. Practitioner research should be implemented in practice and education as a distinct form of research. In continuous research curricular strands in higher professional healthcare education students should acquire sufficient research self-efficacy and the experience that practitioner research can enhance professional learning and practice development.
\end{abstract}

DESCRIPTORS: Applied research. Innovation. Health care sector. Education, higher. Staff development. Learning.

\section{INTRODUCTION}

In the last decade there has been increased attention focused on practitioner research in the practice and education of healthcare professionals in the Netherlands. In this article we reflect on practitioner research as a method for professional learning and practice development which has been taught for a number of years now in many institutes for higher professional healthcare education in the Netherlands.

Practitioner research in healthcare consists of empirical studies conducted by practitioners in order to answer questions resulting from their practice. The research takes place as an interaction between the practitioner doing the research and his/her work environment. The primary goal of practitioner research is to understand and/or improve one's own practice. ${ }^{1-2}$ The main distinctive feature of practitioner research is that it is undertaken by a practitioner. Practitioners are professionals who have a role that involves direct practice with service users. ${ }^{3}$

First we will explain which recent developments in the practice and education of healthcare professionals in the Netherlands have led to the increased interest in practitioner research. Next, we will present the aim of practitioner research and the distinguishing characteristics of the research approach. We will conclude our article with recommendations based on our experiences in the implementation of practitioner research in higher professional healthcare education. 
PERSPECTIVES ON PRACTITIONER RESEARCH AS A PROFESSIONAL LEARNING STRATEGY AND PRACTICE DEVELOPMENT APPROACH FOR HEALTHCARE PROFESSIONALS

\section{Developments in the Dutch healthcare systems}

We observe three main reasons for the increased interest in practitioner research in healthcare in the Netherlands.

Firstly, political, cultural, technological and social developments have led to continuous change in clinical practice in the Netherlands influencing both the quality and quantity of the care demanded. ${ }^{4}$ The demand for care has risen due to an ageing population, increasingly complex health issues and technical and medical advances. These put pressure on the affordability and accessibility of care. It has become necessary for patients and healthcare professionals to work more closely together as partners in dealing with health issues. In addition, a stronger emphasis is put on prevention and wellbeing and care will increasingly take place at home.

These different approaches to care require sufficiently educated healthcare professionals to offer patient-centred services in multi or interdisciplinary teams: broadly trained, flexibly employable and competent in dealing with technology and changing demands for care and services in the area of healthcare and wellbeing. ${ }^{5-6}$ Dutch healthcare professionals have to work in a rapidly changing landscape and their daily practice is highly influenced by the ongoing changes. Work routines acquired in the past often do not suffice. Working in a highly complex society demands lifelong learning and the maintenance and further development of non-routine competencies. $^{7}$

An analytic, inquisitive and reflective capacity is playing an increasingly important role for healthcare professionals to function optimally and to improve clinical practice through innovation. Learning is regarded as a natural element of professional practice. ${ }^{8}$ The Health Council of the Netherlands speaks of a need for an innovative professional practice in which learning organisations encourage collaboration, curiosity, knowledge exchange and two-way critical questioning. ${ }^{9}$

Secondly, in the Netherlands there is a persistent gap between academic research in universities and research institutions and the use and application of research results in organisations and insti- tutions. ${ }^{10}$ The implementation of scientific knowledge and products appears to be problematic in healthcare. ${ }^{9-10}$ One of the problems lies in the linear process of knowledge transfer in which academic researchers develop the knowledge which is then transformed into design and development activities by intermediaries which in turn develop new methods for practice. ${ }^{11}$

A disadvantage of the approach is that it does not recognize and integrate the knowledge and expertise of the healthcare professionals and their patients and clients. ${ }^{10}$ This approach to generate knowledge can also be described as ' mode 1' knowledge production. ${ }^{12}$ The Dutch Ministry of Education, Culture and Science states that this concept is out of date. ${ }^{13}$ The approach does not function because it assumes that knowledge development takes place outside of practice, thus dividing those who develop knowledge from those who use knowledge, the knowledge being rather abstract and therefore not directly applicable in practice. ${ }^{11}$ The approach seeks to connect knowledge with action but does not take into account the complexity of learning in context.

The third reason is that developing knowledge by using research activities fits with the dominant view on learning in the Netherlands. Constructivism has become one of the major approaches in teaching and learning in Dutch education. Constructivism is generally the approach that learners construct their own knowledge from interpreting their experiences. ${ }^{14}$ Based on constructivist learning theories, project-based, problem-based and competencybased programmes have been introduced having in common the use of authentic learning contexts and forms of self-directed learning, aimed at active learning and knowledge construction. ${ }^{15}$

\section{Developments in Dutch higher professional healthcare education}

The developments in Dutch healthcare and recent ideas about knowledge valorisation and learning have led to changes in higher professional healthcare education.

In the Netherlands there are two main types of higher education institutes: research universities offering an academic degree with a focus on theory and universities of applied sciences offering professional education. More and more universities of applied sciences are expected to bridge the gap between the knowledge generated by traditional research institutions and the innovations coming from professional practice. ${ }^{13}$ 
In 2009 the Education Council of the Netherlands (HBO-raad) stated that students in professional training programmes should acquire research competencies, but without specifying what these competencies were. ${ }^{16}$ As a consequence, the development of research curricula has led to discussions about the kind of research future professionals should learn to conduct. The overall picture which has emerged in Dutch higher professional education is that research conducted by students should primarily enhance the performance of professional duties and support practical work. ${ }^{17}$ Each higher professional study programme should offer a continuous research curricular strand, focusing on the development of inquiry-based learning. Students should become familiar with research knowledge about and for their profession and be able to use this knowledge in practice by implementing research activities in their work.?

Research competencies and professional competencies are both interrelated and distinct. In the process of conducting research, a student should acquire and utilize professional knowledge, skills and attitudes and thus develop his or her professional competencies. ${ }^{18}$ Professionals should have an inquisitive capacity consisting of three basic components. They should (1) have an inquisitive attitude (inquiry as a stance), (2) the ability to use knowledge and expertise provided by others and (3) the ability to carry out research projects in their own professional practice. ${ }^{17,19}$ The challenge for the institutes of higher professional education is to incorporate these components in their study programmes.

Accordingly, the institutes for higher professional education offering courses in healthcare have to prepare students to deal with the pace of the changes in the demand for care. The exploratory committee of Higher Education for Health advocates that the healthcare professional actively learns about his or her practice. ${ }^{6}$ Professional practice develops through the interaction of the professional with the unique features of his or her own workplace. The reflective practitioner learns about his or her practice and therefore becomes a better practitioner. ${ }^{20}$ Tacit knowledge from daily practice is made explicit and available to others; this is also called practice-based evidence by some. ${ }^{21}$ The future healthcare professional is a reflective practitioner who can appropriately assess research literature and can contribute to practitioner research. ${ }^{6}$ Increasingly, institutes for higher professional healthcare education have implemented continuous research curricular strands to teach students to conduct practitioner research.

\section{Practitioner research as a professional learning strategy and practice development approach}

We distinguish between three key objectives in research. The first objective is to develop or test theories in order to produce generalizable knowledge. Fundamental research generally focusses on the development and verification of theory on fundamental social or health issues and aims to contribute to the scientific discourse. The second objective of research is to develop knowledge which is applicable in a broad professional context. This is often referred to as applied research. This kind of research focuses on general problem solving and delivers applied knowledge related to specific problems. The third objective is to find answers to questions in a particular professional situation in order to better understand the situation and, if required, to improve it. ${ }^{1-2,22}$

Practitioner research seeks to understand and improve one's own practice and to develop context bound knowledge. ${ }^{1,2}$ Potential benefits arising from practitioner research involve the understanding of methods and research process, question framing, improved intervention and delivery, the identification of hidden issues and the affirmation of ways of working e.g. the challenge of assumptions. ${ }^{3}$ In cases where practitioner research is explicitly focused on developing new, innovative forms of practice, we speak of innovation-oriented practitioner research. The researcher intends to improve practice by designing and systematically testing a new concept or approach which is theory-based and which is intended to be useful to the stakeholders involved. ${ }^{1-2}$

An important feature of practitioner research is that it is a form of inquiry that is done by or with insiders into an organisation or community, but never to or on them. In practitioner research the insider or practitioner is at the centre of the research. Practitioner research implies research from an insider perspective, involving learning in and through action and reflection. ${ }^{23-24}$

An epistemological principle of practitioner research is its role as a method for generating knowledge in the interest of professional learning and professional development taking as its premise that experience constitutes the basis for learning. ${ }^{25-26}$ Practitioner research arises from practice problems or practitioners' questions in response to particular practical situations they are confronted with. People 
learn and change as a result of the integration of concrete and emotional experiences with cognitive processes. ${ }^{27}$

Practitioner research builds on the experiential learning cycle as described by Kolb. Research activities enhance the quality of the stages of experiential learning of professionals so that they can better develop local and action-oriented knowledge. ${ }^{1-2}$ At the heart of the learning process is an ongoing process of reflection and interaction. Communication bends back into one's own experiences and thus largely refers to one's own interpretations, assumptions and concerns. ${ }^{26}$ Tacit knowledge is made explicit and existing knowledge is reconfigured into new forms. ${ }^{28}$

Practitioner research starts with a problem identified in a practice setting. It is important that the professional questions cherished assumptions and routines and that he or she sees the connection with the underlying vision on healthcare..$^{1-2}$ Reflection precedes action. The first research activity is the identification, analysis and description of the problem experienced in daily practice. The practitioner researcher undertakes different activities to acquire insight into the practice problem from a number of perspectives. Involving and integrating multiple perspectives is essential to arrive at joint and shared understanding, the starting point being that each person and perspective can illuminate only part of reality. ${ }^{12}$

Practitioner research distinguishes itself from spontaneous reflection, because the reflective process is deliberately and systematically undertaken and requires some form of evidence to support assertions. ${ }^{23}$ Three levels of reflection can be distinguished, namely the instrumental, the substantial and the critical level. Reflection at the instrumental level focuses on the visible actions of the professional in practice. Substantial reflection concerns the underlying principles of the behaviour including the visions on healthcare. Finally, the reflection can be at a critical level: this relates to the moral, ethical and other normative considerations of the professional. ${ }^{29}$ The professional has to balance a performance orientation (move forward, plan and focus on the result) and a sense-making orientation (slow down, ask questions and bring in a multi perspective). ${ }^{30}$

Practitioner researchers engage in individual or collective inquiry seeking to understand problems and issues that arise from their own professional practice. This can involve the effectiveness of work, the needs of the people served, and the services delivered. The approach is based on the ontological assumption that there are multiple interpretations of reality, that these interpretations can be described on the basis of general patterns and specific features of professional practice, and that there is a strong relationship between the research results and the specific context of the professional practice investigated. ${ }^{1,2}$ Doing practitioner research means, amongst other things, accommodating different perspectives in understanding and improving practice. ${ }^{1-2,23}$ Stakeholders in healthcare need a clear image of an innovation in order to be able to take the next step in the implementation process. ${ }^{10}$

Making use of what others have written in relation to practice is an essential perspective, not only where conducting practitioner research is concerned, but also as a core competence for professional development. ${ }^{29}$ In practitioner research theory helps one to understand practice and reflect on oneself as a professional. It also offers insight into possible solutions and provides a language to communicate reflections and findings. However, it can be argued that in the professional domains of education, social work and healthcare, research can indeed offer us insight into the possible relationships between our actions and their consequences, but will not guarantee that what worked in the past will in the same way work in the future. ${ }^{31}$

Practitioner research deliberately seeks to generate local knowledge and theories by exploring different perspectives and encouraging the integration of theory and practice by relating existing insights to a specific professional context. ${ }^{1-2}$ The phase of theory questioning practice can be followed by a phase of practice questioning theory. ${ }^{26}$

The practitioner researcher chooses quantitative or qualitative methods, or a combination of both for data collection to get a multiple perspective insight into the practice problem. The use of mixed methods in research is becoming an important approach when investigating complex health-related topics, hearing the voices of participants and thus gaining a more complete understanding of the issues involved..$^{32}$ The practitioner researcher uses instruments such as checklists for written sources, interview guides, questionnaires, tests, observation instruments or logs to systematically collect data. Additionally, visual, dramatic, narrative or job specific instruments can be used to collect data.

Research activities do not take place for practice, but with practice. ${ }^{1-2,11}$ An important principle in practitioner research projects is the continuous process of dialogue with stakeholders in practice and peers. Practice is seen in relation with others, as a process of dialogue and encounter. ${ }^{28}$ Practice is 
questioned and data are collected and analyzed in cooperation with colleagues and clients or patients to improve services. The systematic participation of primary users in evaluations can lead to an increased expertise on the part of the participants and the perception of the results as congruent with daily practice. ${ }^{33}$ In healthcare, practitioner research can take the form of Participatory Health Research (PHR) in which the participation of those whose life or work is the subject of the research in all stages of the research process is maximized. This includes the formulation of the research question and goal, the development of a research design, the selection of appropriate methods for data collection and analysis, the implementation of the research, the interpretation of the results, and the dissemination of the findings. ${ }^{24}$

From a pragmatic epistemological perspective, knowledge, concepts and words are part of a life form, of practical contexts and patterns and the development of professional concepts must, therefore, be based on professional practice. ${ }^{34}$ The relationship between thinking, knowledge, language and culture can be expressed by the concept of 'discourse community': a community of language users distinct from other communities by its own way of knowing and thinking, its own value system, its own interpretation of (part of) reality..$^{29}$ Learning takes place by means of dialogue in a discourse community. ${ }^{35}$

From a critical epistemological perspective, it is necessary to develop professional knowledge through cooperative research processes. ${ }^{34}$ Practitioner research supports a bottom-up approach to organizational learning and change. ${ }^{1-2}$ It can contribute to practice development by making tacit knowledge explicit. ${ }^{36}$ Practice development as a field of inquiry takes the form of a continuum; at the mid-point practice developers are positioned as practitioner-researchers or practice evaluators engaging in rigorous individual or collective inquiry into the effectiveness of individual, workplace and organisational strategies. ${ }^{37}$

Practitioner research as a form of PHR is grounded in the reality of daily work at a specific place and time. The issue being researched is located in the social system that is likely to adopt changes that result from the research process. ${ }^{24}$ The knowledge is produced in the context of application. Practitioner research produces local knowledge and theories.

Practitioner research should be implemented as a research approach in its own right instead of a simpler version of academic research. ${ }^{1-3}$ Depending on the aim of the research project, the assessment follows its own specific validity criteria. ${ }^{1-2,23}$ Firstly, the practitioner research project can be valued on the basis of its contribution to the professional development of the practitioner researcher. Secondly, the collective development of stakeholders in the organization can be the test. This is also called the catalytic validity of the research project. ${ }^{23}$ Thirdly, the rigor of the research process can be assessed. The fourth criterion is the transparency of the research. The degree to which the research tallies with daily professional practice is the fifth criterion. This reflects the criterion of process validity. ${ }^{23}$ An important goal of practitioner research is to contribute to the solution of the practice problem. The extent to which the practice problem has been solved is another criterion. This is also referred to as the outcome validity. ${ }^{23}$ Finally, the democratic and dialogic validity can be the yardstick: this relates to the quality and the intensity of the communication with and participation of stakeholders and internal or external critical friends. ${ }^{23}$

\section{Recommendations for the implementation of practitioner research in higher professional healthcare education}

Institutes for higher professional education are still struggling with redefining their position as universities of applied sciences in the field of science and higher education. On the one hand they have to legitimise themselves to the academic community, and on the other hand, to the practitioner communities. Traditionalist positivist views of research and theory still dominate much institutional thinking and practice. ${ }^{28}$

The discussion in many Dutch Universities of applied sciences shows that this also holds true for the Netherlands. There are calls for universities of applied sciences to come up with one set of quality criteria, but especially in the social sciences paradigmatic views differ significantly. Additionally, research aims and research questions can co-define quality: often an informed decision must be taken between practical relevance and methodological rigor. ${ }^{38}$ Practitioner research is a distinct form of research practice. Traditional positivist or naturalist paradigms do not capture the dilemmas faced by practitioner researchers. ${ }^{23}$

In the development and implementation of continuous research curricular strands to prepare students to conduct practitioner research the discussion should be about the underlying ontological, 
epistemological, ethical and methodological principles. A point of attention has to be that practitioner researchers combine their roles as researcher, professional and colleague. Clear choices will have to be made about the instruction and assessment of practitioner research projects.

Practitioner research projects offer students the opportunity to learn the profession by using both theoretical concepts and professional language to analyse and describe processes in professional practice and make explicit what is felt to be 'good' or 'bad' practice. Making implicit and tacit knowledge explicit is conditional for both individual and collective professional learning. The student has to be challenged to make the connection between the instrumental level and the substantial and critical levels of reflection and make this explicit. This requires a review of his or her own thinking from both his or her own perspective and other perspectives, as well as a command of the professional language.

Previous frameworks need to be identified, unfolded and deployed to enhance professional learning and to rebuild praxis. ${ }^{39}$ This is very much the case in innovation-oriented practitioner research where theoretical and practical theories intertwine. Practitioner research projects can, in addition to lectures and practical training, be beneficial for students to become full members of their professional discourse community. However, students should be provided with sufficient research self-efficacy and the experience that practitioner research can actually help them to understand and improve practice. In other words, the experience should, on reflection, be a positive one and help them to investigate their own practice effectively. This will assumingly motivate them to continue to engage in individual or collective practitioner research to understand problems and issues that arise from their own future practice enhancing the performance of professional duties and supporting practical work.

\section{CONCLUSIONS}

Daily practice in Dutch healthcare is greatly influenced by the ongoing political, cultural, technological and social developments requiring lifelong learning and the maintenance and further development of non-routine competencies. Recent ideas about knowledge valorisation and learning have led to question the linear process of knowledge transfer which is still quite dominant in Dutch healthcare. There is a demand for professionals in healthcare with an inquisitive attitude, the ability to use knowledge and expertise provided by others and the competence to carry out research projects in their own professional practice.

Practitioner research is seen as an effective professional learning strategy to promote learning on the job. Healthcare professionals and their patients and clients are at the heart of the research process. The research approach promotes the use of theory and recognizes practical knowledge and expertise of the healthcare professionals and their patients and clients. It contributes to the empowerment of the professional who is in charge of his or her own learning process and is actively involved in constructing local knowledge and improving practice with stakeholders. Practitioner research is a useful practice development approach for healthcare professionals to research, reflect on and improve their everyday practice.

An important task for institutes of higher professional healthcare education in the Netherlands is to prepare students to become healthcare professionals who are indeed equipped to conduct research, reflect on and change their everyday practice in collaboration with important others. Many institutes have now developed and implemented continuous research curricular strands to enhance these professional learning competencies of their students. Practitioner research should be implemented as a distinct form of research and students should be provided with sufficient research selfefficacy and the experience that practitioner research can enhance professional learning and practice development.

\section{REFERENCES}

1. Van der Donk C, Van Lanen B, Wright MT. Praxisforschung im Sozial- und Gesundheitswesen. Bern (CH): Verlag Hans Huber; 2014.

2. Van der Donk C, Van Lanen B. Praktijkonderzoek in de zorg en welzijn. 2nd ed. Bussum (NL): Uitgeverij Coutinho; 2016.

3. Shaw I, Lunt N, Mitchell F. Practitioner research in social care: a review and recommendations. London (UK): School for Social Care Research; 2014.

4. Steinert Y. Faculty development: core concepts and principles. In: Steinert Y. Faculty Development in the health professions. a focus on research and practice. Dordrecht (NL): Springer Science and Business Media; 2014. p.3-25.

5. Terheggen S. De zorg verandert. Wat betekent dit voor het onderwijs?. Vakblad voor Opleiders Gezondheidszorgonderwijs. 2013; 1:8-12. 
6. Verkenningscommissie HGZO (NL) Voortrekkers in verandering. zorg en opleidingen - partners in innovatie. Hague (NL): HBO-raad; 2013.

7. Onderwijsraad (NL). Meer innovatieve professionals. Den Haag (NL): Onderwijsraad; 2014.

8. Coenders M, Prill A. Communities of practice: Lerngemeinschaften entwickeln und gestalten. In: Cendon E, Flacke LB (Hrsg.) Lernwege gestalten: Studienformate an der Schnittstelle von Theorie und Praxis. Veranstaltung der wissenschaftlichen Begleitung, 5. bis 6. Dezember 2013.Tagungsband der wissenschaftlichen Begleitung des BundLänder-Wettbewerbs Aufstieg durch Bildung: offene Hochschulen. Berlin (DE). 2014. p. 60-71.

9. Gezondheidsraad (NL). Sociaal werk op solide basis. Den Haag (NL): Gezondheidsraad; 2014.

10. Grol R, Wensing M. Implementatie. Effectieve verbetering van de patiëntenzorg. 7 th ed. Houten (NL): Bohn Stafleu van Loghum; 2017.

11. Kwakman K. Anders leren, beter werken (lectorale rede). Nijmegen (NL): Hogeschool van Arnhem en Nijmegen; 2003.

12. Abma TA, Cook T, Rämgård M, Kleba E, Harris J, Wallerstein N. Social impact of participatory health research: collaborative non-linear processes of knowledge mobilization. J Educ Action Res [Internet]. 2017 [cited 2018 Mar 13]; 25(4):489-501. Available from: https://doi.org/10.1080/09650792.2017.1329092

13. Ministerie van OCW (NL). Wetenschapsvisie 2025 Keuzes voor de toekomst. Den Haag (BL): Ministerie van OCW; 2014.

14. Doolittle PE. Complex Constructivism: A theoretical model of complexity and cognition. Inter J Teach Learning High Educ. 2014; 26(3):485-98.

15. Van Bommel M, Boshuizen HPA, Kwakman K. Appreciation of a constructivist curriculum for learning theoretical knowledge by social work students with different kinds and levels of learning motivation. Inter J Educ Res. 2015; 71: 65-74.

16. HBO-raad (NL). Kwaliteit als opdracht. Den Haag (NL): HBO-raad; 2009.

17. Andriessen D. Drie misverstanden over onderzoek in het hbo. Hoger Onderwijs Management. 2016 Oct [cited 2017 Feb 1]; 2016(05). Available from: http:/ / www. onderzoekscoach.nl/wp-content/uploads/2016/11/ Andriessen-2016-Drie-misverstanden-overonderzoek-in-het-hbo-weggenomen.pdf

18. Verburgh A, Elen J. Vormgeving van onderzoeksintegratie in het curriculum. In: Griffioen DME, Visser-Wijnveen GJ, Willems J, editors. Integratie van onderzoek en onderwijs: effectieve inbedding van onderzoek in curricula. Groningen (NL): Noordhoff; 2013.

19. Andriessen D. Praktisch relevant én methodisch grondig. Dimensies van onderzoek in het HBO. Utrecht (NL): Hogeschool Utrecht; 2014.
20. Scho $\square \mathrm{n}$ DA. The reflective practitioner: How professionals think in action. New York: Basic Books; 1983.

21. Wright MT, Kilian H, Brandes S. Praxisbasierte Evidenz in der Prävention und Gesundheitsforderung bei sozial benachteiligten. Das Gesundheitswesen. 2013; 75(6):380-5.

22. Wright MT, Van der Donk C, Van Lanen B. Partizipative Forschung für die Soziale Arbeit in der Psychiatrie. In: Bischkopf J, Deimel D, Walther C, Zimmermann RB, editors. Soziale Arbeit in der Psychiatrie. Köln (DE): Psychiatrie Verlag; 2017. p. 458-70.

23. Herr K, Anderson GL. The action research dissertation: A guide for students and faculty. 2nd ed. Thousand Oaks (US): Sage; 2014.

24. International Collaboration for Participatory Health Research. Position paper 1: what is participatory health research? Berlin (DE): ICPHR; 2013 [cited 2017 Jan 8]. Available from: http://www.icphr. org/uploads/2/0/3/9/20399575/ichpr_position_ paper_1_defintion_-_version_may_2013.pdf

25. Heron J, Reason P. Extending epistemology within a co-operative inquiry. In: Reason P, Bradbury H, editors. Handbook of action research: participative inquiry and practice. London (UK): Sage; 2008. p. 366-80.

26. Winter R, Burroughs S. Learning from experience: principles and practice in action-research. London; New York (US): Falmer Press; 1989.

27. Kolb DA. Experiential learning. Englewood Clifs, (US): Prentice Hall; 1984.

28. McNiff J. Action research: principles and practice. 3rd ed. London (UK): Routledge; 2013.

29. Van de Ven P. Reflecteren: het belang van kennis. Tijdschrift voor lerarenopleiders. 2009; 30(1):22-7.

30. Derksen K. Creating developmental space for better team results [these]. Amsterdam: Vrije Universiteit; 2017 [cited 2017 Feb 6]. Available from: http:/ / dspace. ubvu.vu.nl/bitstream/handle/1871/54818/title\%20 page.pdf? sequence $=2 \&$ isAllowed $=y$

31. Biesta GJJ. De vorming van de democratische professional. Over professionaliteit, normativiteit en democratie. Waardenwerk: J Humanistic Stud. 2014; 56: 7-18.

32. Guetterman TC, Fetters MD, Creswell JW. Integrating quantitative and qualitative results in health science mixed methods research through joint displays. Ann Fam Med [Internet]. 2015 [cited 2017 Jan 12]; 13(6):55461. Available from: https:// doi.org/10.1370/afm.1865

33. Brandes S, Schaefer I. Partizipative Evaluation in Praxisprojekten. Chancen und Herausforderungen. In: Wright MT, editor. Prävention und Gesundheitsförderung. Partizipative Gesundheitsforschung. 2013; 8(3):132-37.

34. Hiim H. Educational action research and the development of professional teacher knowledge. In: 
Gunnarsson E, Hansen HP, Nielsen BS, Sriskandarajah $\mathrm{N}$, editors. Action research for democracy: New ideas and perspectives from Scandinavia. London (UK): Routledge; 2016.

35. Bruffee KA. Social construction, language, and the authority of knowledge: a bibliographical essay. College English. 1986; 48(8):773-90.

36. Van der Donk C, Kuijer-Siebelink W. Practitioner research to promote practice development: the continued development by means of practitioner research of a multidisciplinary learning environment within neurorehabilitation care for older persons. Inter Prac Develop J [Internet]. 2015 [cited 2017 Jan 12]; 5(2). Available from: http:/ / www.fons.org/library/ journal/volume5-issue2/article5

37. Dewing J, Titchen A, McCormack B. Practice development and the potential for integrating transformational practice with research. A response to editorial: Thompson D, Watson R, Quinn T, WorrallCarter L, O'Connell B. 2008. Practice development: what is it and why should we be doing it? Nurse Educ Pract [Internet]. 2009 [cited 2017 Jan 12]; 9(1):1-4. Available from: https://doi.org/10.1016/j. nepr.2008.11.002

38. Hageman C, Andriessen D. Praktijkgericht onderzoek in de etalage. Den Haag: Vereniging Hogescholen; 2016.

39. Gomez SS, Moya JLM. Interactions between the epistemological perspective of nursing educators and participants in educational programs: limits and opportunities toward the development of qualification processes for the promotion of self-care in health. Texto Contexto Enferm [Internet]. 2015 Jun [cited 2017 Jan 12]; 24(2):301-9. Available from: http://www. scielo.br/scielo.php?script=sci_arttext\&pid=S010407072015000200301\&lng=pt 